\title{
Aerosolization of Ebola Virus Surrogates in Wastewater Systems
}

\author{
Kaisen Lin
}

Thesis submitted to the faculty of the Virginia Polytechnic Institute and State University in partial fulfillment of the requirements for the degree of

\author{
Master of Science \\ In \\ Civil Engineering
}

\author{
Linsey C. Marr, Chair \\ Zhen $\mathrm{He}$ \\ Amy Pruden
}

\author{
August $11^{\text {th }}, 2016$ \\ Blacksburg, VA
}

Keywords: Ebola, virus, bioaerosol, inhalation, wastewater

Copyright (C) 2016, Kaisen Lin 


\section{Aerosolization of Ebola Virus Surrogates in Wastewater Systems}

\section{Kaisen Lin}

\section{Academic Abstract}

Recent studies have shown that Ebola virus can persist in wastewater, and the potential for the virus to be aerosolized and pose a risk of inhalation exposure has not been evaluated. We considered this risk for three wastewater systems: toilets, a lab-scale model of an aeration basin, and a lab-scale model of converging sewer pipes. We measured the aerosol size distribution generated by each system, spiked Ebola virus surrogates into each system, and determined the emission rate of viruses into the air. While the number of aerosols released ranged from $10^{5}$ to $10^{7}$ per flush from the toilets or per minute from the lab-scale models, the total volume of aerosols generated by these systems was $\sim 10^{-8}$ to $10^{-7} \mathrm{~mL}$ per flush or per minute in all cases. The Ebola virus surrogates MS2 and Phi6, spiked into toilets at an initial concentration of $10^{7} \mathrm{PFU} \mathrm{mL}^{-1}$, were not detected in air after flushing. Airborne concentrations of MS2 and Phi6 were $\sim 20 \mathrm{PFU} \mathrm{L}^{-1}$ and $\sim 0.1 \mathrm{PFU} \mathrm{L}^{-1}$, respectively, associated with the aeration basin and sewer models. This corresponds to

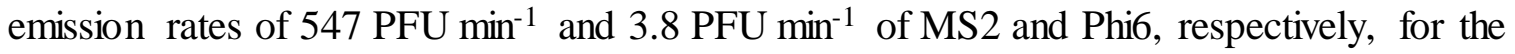

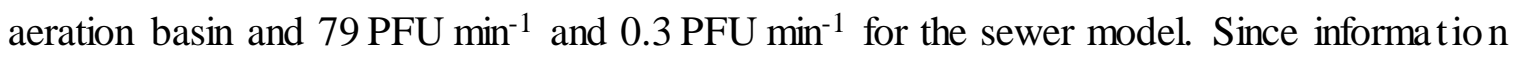
on the aerosolization of Ebola virus is quite limited, these emission rates can greatly help inform risk assessment of inhalation exposure to Ebola virus. 


\section{Acknowledgements}

I would like to express my sincere appreciation to my advisor, Dr. Linsey Marr, for her support and encouragement on my way finishing this thesis. Her enthusiasm to pursue great work and positive attitude towards life influenced me a lot. I am very grateful to have her being my advisor.

I would also like to thank my committee members, Dr. Zhen He and Dr. Amy Pruden, for their instructions and dedication of time. The knowledge and expertise they provided has been extremely valuable throughout my studies.

I am very glad to meet great fellow researchers at the $\mathrm{AIR}^{2}$ research group and Environmental and Water Resource Program and at Virginia Tech. I want to thank Dr. Marina E. Vance, Dr. Eric Vejerano, Dr. Mari Titcombe Lee, Dr. Ray David, Dr. Aaron Justin Prussin, Dr. Hannah Rogers, Dr. Yaoxing Wu, Mr. Michael Milazzo and Ms. Zihan Wang for their contribution to my research and studies.

I would like to thank my girlfriend, Ms. Minzhe Zhang, for her understanding and tolerance. I appreciate her sacrifice in our relationship.

Finally, I would like to express my deepest thanks to my parents, who are thousands of miles away from me in the past two years but loving me every single minute. Many thanks to their understanding and support to my decision of studying abroad, without which this thesis would not be possible. Thank them for always being proud of me. 


\section{Table of Contents}

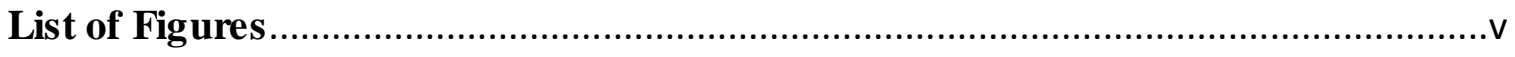

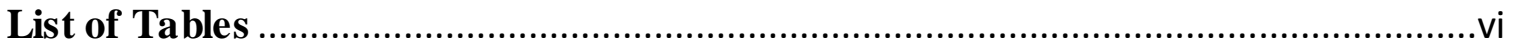

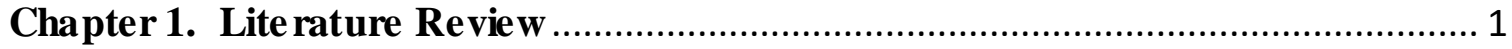

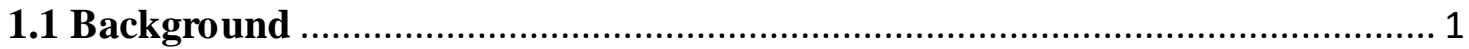

1.2 Potential for Ae rosol Trans mission via Wastewater .................................... 3

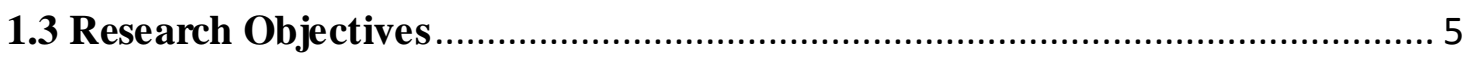

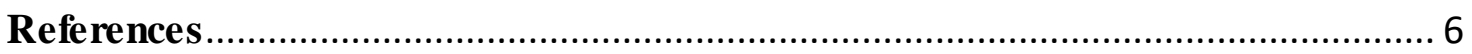

Chapter 2. Ae rosolization of Ebola Virus Surrogates in Waste water Systems ......... 10

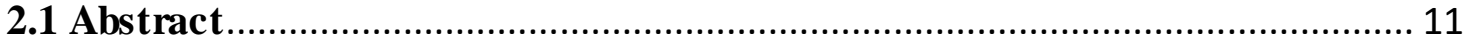

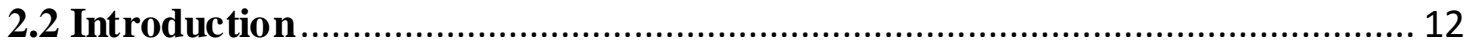

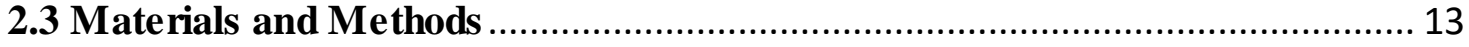

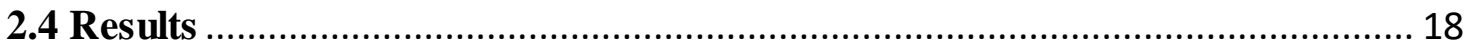

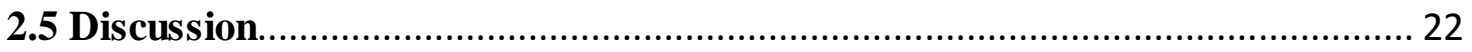

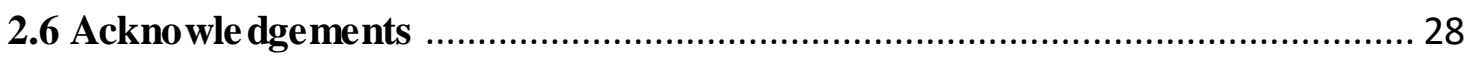

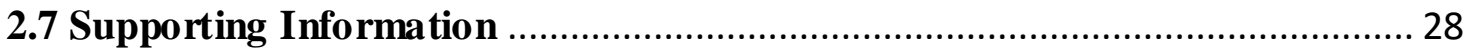

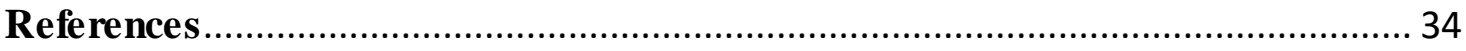

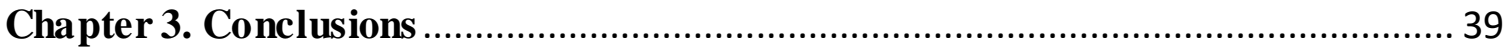

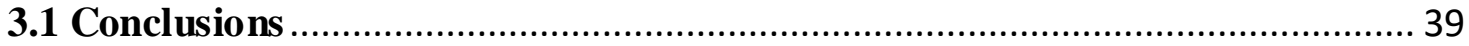

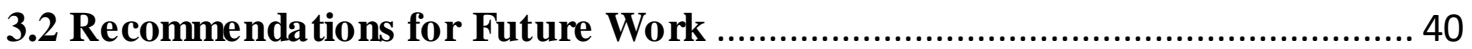




\section{List of Figures}

Figure 1. Examples of aerosol size distributions generated by wastewater systems: (a) flush toilet; (b) aeration basin; (c) converging sewer pipes. The red curve represents the composite data from SMPS and APS. The black curve represents the fit to the composite

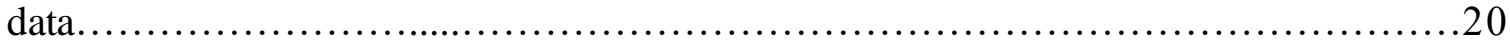

Figure 2. MS2 concentrations in air and corresponding mixed liquor from which they were generated in lab-scale models of an aeration basin and converging sewer pipes with MS2 at an initial concentration in mixed liquor of $10^{7} \mathrm{PFU} \mathrm{mL}^{-1} \ldots \ldots \ldots \ldots \ldots \ldots . \ldots 21$

Figure 3. Phi6 concentrations in air and corresponding mixed liquor from which they were generated in lab-scale models of an aeration basin and converging sewer pipes with Phi6 at an initial concentration of in mixed liquor $10^{7} \mathrm{PFU} \mathrm{mL}^{-1} \ldots \ldots \ldots \ldots \ldots \ldots \ldots . \ldots 21$

Figure S1. Experimental setup for measurement of toilet-generated aerosols ..........34

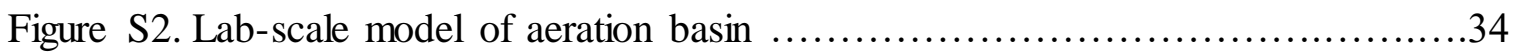

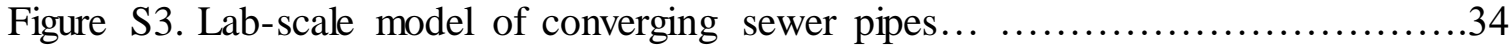

Figure S4. Wall loss coefficient curve for aeration basin model......................36

Figure S5. Wall loss coefficient curve for converging sewer pipes model ..............36 


\section{List of Tables}

Table 1. Characteristics of aerosols generated per activity or per unit of time by flush toilets and lab-scale models of an aeration basin and converging sewer pipes......19

Table 2. Emission rates of Ebola virus surrogates by toilets and lab-scale models of an aeration basin and converging sewer pipes................................. 22

Table S1. Characteristics of mixed liquor and anaerobically-digested sludge............33 


\subsection{Background}

\section{Chapter 1. Literature Review}

The current Ebola virus disease (EVD) outbreak in West Africa is the largest in history. It has caused 11,310 deaths as of June 2016 with a fatality rate of $53 \% .^{1}$ The particular strain causing the current outbreak, Zaire ebolavirus, is a member of the Filoviridae family. ${ }^{2}{ }^{3}$ It is believed that as few as 10 infectious viral particles is enough to infect an individual. ${ }^{4-6}$

It is widely accepted that the primary route of Ebola virus (EBOV) transmission is direct contact with the patient and/or infectious body fluids. ${ }^{7}$ However, given that EBOV is a high-consequence pathogen, there are concerns about other routes of transmission. The virus has been identified by reverse-transcription quantitative polymerase chain reaction (RT-qPCR) not just in patients' bodily fluids, such as stool and blood, but also in contaminated needles as well as used masks. ${ }^{8-11}$ Individuals have been infected via fomites, e.g., by direct contact with EBOV-contaminated waste, ${ }^{12}$ rather than direct contact with a patient. Transmission of EVD by a route other than direct contact has been demonstrated in several nonhuman primate studies. ${ }^{13},{ }^{14}$ In one, two sets of monkeys occupied separate cages that were $3 \mathrm{~m}$ away from each other so that there was no direct contact between the monkeys. Two control monkeys died from EVD at 10 and 11 days after the last

experimental inoculated monkey died. ${ }^{15}$ Weingartl ${ }^{16}$ reported the first experimental interspecies EBOV transmission from pigs to macaques without direct contact. These findings support the hypothesis that EBOV can be transmitted in some cases by inhalation of airborne infectious virus. 
EVD patients' diarrhea and blood may contain high concentrations of the virus: $10^{7}$ genome copies $\mathrm{mL}^{-1}$ and $10^{8}$ genome copies $\mathrm{mL}^{-1}$, respectively. ${ }^{17}$ Infected individuals can produce up to $9 \mathrm{~L}$ of liquid waste per day, which means disposal of a large volume of EBOV-contaminated waste is required. ${ }^{18,19}$ According to guidance from the World Health Organization (WHO), liquid waste from Ebola victims can be directly disposed in the sanitary sewer without disinfection. ${ }^{20}$ This recommendation has raised questions among environmental engineers because limited data are available about the fate of EBOV in wastewater systems. In the absence of such data, the potential for wastewater systems to serve as a vehicle for EVD transmission, particularly for those who work closely with sewage, cannot be dismissed. ${ }^{21}$

In response to this knowledge gap, recent studies have focused on the persistence and partitioning of EBOV in wastewater systems. For EBOV spiked into sterile wastewater, approximately 99\% reduction of viral titer occurred within one day, but infectious EBOV persisted for all 8 days of the test. ${ }^{22}$ Similar results were observed with EBOV surrogates. In sewage, $4 \log _{10}$ inactivation of Phi6, an enveloped bacteriophage, was achieved in 2 and 6 days at $30{ }^{\circ} \mathrm{C}$ and $22{ }^{\circ} \mathrm{C}$, respectively. ${ }^{23}$ The effects of matrices and environmental conditions on the stability of EBOV in sewage were also noticeable. ${ }^{24}$ A study investigating the partitioning of EBOV surrogates among liquid, biosolids, and four different material surfaces commonly used in wastewater systems found that at least 94\% of virions partitioned into the liquid fraction (Titcombe Lee et al. 2016). Thus, the virus would maintain its mobility in wastewater systems. Another study reported that $77 \%$ of Phi6 virions were found in the liquid fraction of wastewater. ${ }^{25}$ It can be concluded from the available results that EBOV can survive in wastewater for at least a couple of days. As 
the possibility of EBOV transmission via wastewater cannot be completely ruled out, the results of these studies emphasize the importance of a conservative approach to handling EBOV-contaminated wastewater. ${ }^{22}$

\subsection{Potential for Aerosol Transmission via Wastewater}

Given that (1) aerosol transmission of EVD has been demonstrated in animal models, (2) the virus is present in high concentrations in diarrhea, and (3) the virus can survive in wastewater, it is theoretically possible that EBOV could be transmitted by aerosolization of wastewater. We have identified three possible sources of aerosolization of EBOV from wastewater. One is flush toilets. Studies on aerosol generation by modern flush toilets found that up to 145,000 droplets less than $2 \mu \mathrm{m}$ in size can be produced per flush $^{26}$ Many studies have detected microorganisms in ambient air in bathrooms and on the toilet surface, indicating the production of bioaerosols and the potential for disease transmission. ${ }^{27-31}$ Microorganisms have been detected in air 90 minutes after flushing and $25 \mathrm{~cm}$ above the toilet seat. These aerosolized microorganisms can maintain their viability and spread in ambient air. ${ }^{28,29,31,32}$ The potential for EBOV to spread via this route is not known. Previous studies have focused mainly on bacteria rather than viruses, and they have not measured the full range of aerosol sizes produced by flush toilets. Thus, studies on aerosolization of EBOV or its surrogates by flush toilets will be useful to bridge the knowledge gaps.

A second possible source of aerosolized EBOV is the wastewater collection system. Aerosols may be generated by converging flows in sewer pipes and by high-press ure cleaning, although the literature on this topic is limited. One study reported airborne

concentrations as high as $4.0 \times 10^{4}$ colony-forming units per cubic meter $\left(\mathrm{CFU} \mathrm{m}^{-3}\right)$ of total 
bacteria and $3.0 \times 10^{3} \mathrm{CFU} \mathrm{m}{ }^{-3}$ of coliforms during high-pressure cleaning. ${ }^{33}$ Another study characterized bioaerosols generated in sewage systems indirectly by measuring endotoxin concentrations; endotoxins are a cell wall component of Gram-negative bacteria. ${ }^{34,}{ }^{35} \mathrm{Up}$ to $80 \mathrm{ng} \mathrm{m}^{-3}$ of endotoxin were detected in the air samples. To our knowledge, there are no studies on aerosolization of viruses in sewers.

A third possible source is wastewater treatment plants (WWTPs). Previous studies have demonstrated that bioaerosols can be produced by different units in wastewater treatment plants, such as aeration tanks, grit chambers and trickling filters. ${ }^{36-38}$ The concentration of airborne bacteria has been shown to vary from as low as 4 to 1000s of CFU m ${ }^{-3}$ depending on the species. ${ }^{33,39-41}$ Airborne viruses have been detected at WWTPs as well. Adenovirus and norovirus concentrations as high as $2.27 \times 10^{6}$ genome copies $\mathrm{m}^{-3}$ and $1.42 \pm 1.14 \times 10^{3}$ genome copies $\mathrm{m}^{-3}$, respectively, have been reported. ${ }^{42,43}$ Based on the current literature, it appears that airborne concentration of EBOV at a WWTP may be affected by the treatment process, the concentration of EBOV in wastewater, and the sampling location.

To support development of policy and guidance for minimizing transmission of EVD, quantitative risk assessment of the potential for aerosolization of EBOV from wastewater is needed. One step in risk assessment is estimating exposure to aerosolized virus, which requires prediction of its airborne concentration. An element that is missing from most previous studies on microorganisms aerosolized in wastewater systems is an emission rate or emission factor (i.e., number of virions released per unit of activity, such as per flush or per volume of wastewater treated, as a function of virus concentration in the wastewater). Whereas ambient concentrations reported in previous studies are specific to 
one particular study, an emission rate or emission factor can be used in a model to predict concentrations and inhaled dose more universally under a variety of conditions.

\subsection{Research Objectives}

This study is based on the hypothesis that wastewater systems can generate aerosols containing Ebola virus surrogates. The main objective of this work is to investigate the aerosolization of EBOV surrogates in three wastewater systems: toilets, sewers, and aeration basins. The data collected will be helpful in assessing whether flush toilets may put health care workers at risk by exposing them to EBOV-containing aerosols. It will also provide data for evaluating whether sewer workers and WWTP workers need special personal protective equipment to guard against exposure to EBOV via the inhalation route. The specific research objectives are:

1. Design methods to measure the size distribution of aerosols and aerosol generation rate produced by a flush toilet, lab-scale converging sewer pipes, and a lab-scale aeration basin;

2. Collect aerosol samples produced by the wastewater systems and quantify both the viable and total genome concentration of EBOV surrogates in air;

3. Calculate the emission rate of EBOV surrogates and the potential for human exposure.

Chapter 2, Aerosolization of Ebola Virus Surrogates in Wastewater Systems, addresses these objectives in the format of a manuscript that will be submitted for publication in a peer-reviewed, scientific journal. In the study, we developed experimental models of three wastewater systems, including flush toilets, a lab-scale aeration basin, and lab-scale converging sewer pipes. We used a scanning mobility particle sizer and 
aerodynamic particle sizer to measure the size distribution of aerosols generated by these systems. We also collected air samples and quantified by plaque assay the airborne concentration of Ebola virus surrogates that had been spiked into the wastewater systems. Lastly, we calculated the emission rates of the Ebola virus surrogates from each model.

Chapter 3 concluded this thesis by describing the main results of this work and making recommendations for future work.

\section{References}

1. CDC 2014 Ebola Outbreak in West Africa - Case Counts http:/www.cdc.gov/vhf/ebola/outbreaks/2014-west-africa/case-counts.html

2. Pourrut, X.; Kumulungui, B.; Wittmann, T.; Moussavou, G.; Délicat, A.; Yaba, P.; Nkoghe, D.; Gonzalez, J.-P.; Leroy, E. M., The natural history of Ebola virus in Africa. Microbes Infect. 2005, 7, (7-8), 1005-1014.

3. Team, W. E. R., Ebola virus disease in West Africa - the first 9 months of the epidemic and forward projections. N. Engl. J. Med. 2014, 371, (16), 1481-95.

4. $\quad$ Franz, D. R.; Jahrling, P. B.; Friedlander, A. M.; McClain, D. J.; Hoover, D. L.; Bryne, W. R.; Pavlin, J. A.; Christopher, G. W.; Eitzen, E. M., Clinical recognition and management of patients exposed to biological warfare agents. Jama 1997, 278, (5), 399411.

5. Jelden, K. C.; Gibbs, S. G.; Smith, P. W.; Schwedhelm, M. M.; Iwen, P. C.; Beam, E. L.; Hayes, A. K.; Marion, N.; Kratochvil, C. J.; Boulter, K. C., Nebraska Biocontainment Unit patient discharge and environmental decontamination after Ebola care. Am. J. Infect. Control 2015, 43, (3), 203-205.

6. Johnson, E.; Jaax, N.; White, J.; Jahrling, P., Lethal experimental infections of rhesus monkeys by aerosolized Ebola virus. Int. J. Exp. Pathol. 1995, 76, (4), 227.

7. $\quad$ Osterholm, M. T.; Moore, K. A.; Kelley, N. S.; Brosseau, L. M.; Wong, G.; Murphy, F. A.; Peters, C. J.; LeDuc, J. W.; Russell, P. K.; Van Herp, M., Transmission of Ebola viruses: what we know and what we do not know. MBio 2015, 6, (2), e00137-15.

8. Rodriguez, L.; De Roo, A.; Guimard, Y.; Trappier, S.; Sanchez, A.; Bressler, D.; Williams, A.; Rowe, A.; Bertolli, J.; Khan, A., Persistence and genetic stability of Ebola virus during the outbreak in Kikwit, Democratic Republic of the Congo, 1995. J. Infect. Dis. 1999, 179, (Supplement 1), S170-S176.

9. $\quad$ Formenty, P.; Leroy, E. M.; Epelboin, A.; Libama, F.; Lenzi, M.; Sudeck, H.; Yaba, P.; Allarangar, Y.; Boumandouki, P.; Nkounkou, V. B., Detection of Ebola virus in 
oral fluid specimens during outbreaks of Ebola virus hemorrhagic fever in the Republic of Congo. Clin. Infect. Dis. 2006, 42, (11), 1521-1526.

10. Bausch, D. G.; Towner, J. S.; Dowell, S. F.; Kaducu, F.; Lukwiya, M.; Sanchez, A.; Nichol, S. T.; Ksiazek, T. G.; Rollin, P. E., Assessment of the risk of Ebola virus transmission from bodily fluids and fomites. J. Infect. Dis. 2007, 196, (Supplement 2), S142-S147.

11. Deng, I.; Duku, O.; Gillo, A.; Idris, A.; Lolik, P.; el Tahir, B.; Tembura, W.; Warille, N.; Knobloch, J.; Cornet, M., EBOLA HEMORRHAGIC-FEVER IN SUDAN, 1976-REPORT OF A WHO INTERNATIONAL STUDY TEAM. Bull. W.H.O 1978, 56, (2), 247-270.

12. Edmunds, K. L.; Elrahman, S. A.; Bell, D. J.; Brainard, J.; Dervisevic, S.; Fedha, T. P.; Few, R.; Howard, G.; Lake, I.; Maes, P., Recommendations for dealing with waste contaminated with Ebola virus: a Hazard Analys is of Critical Control Points approach. Bull. W.H.O 2016, 94, (6), 424-432.

13. Kobinger, G. P.; Leung, A.; Neufeld, J.; Richardson, J. S.; Falzarano, D.; Smith, G.; Tierney, K.; Patel, A.; Weingartl, H. M., Replication, pathogenicity, shedding, and transmission of Zaire ebolavirus in pigs. J. Infect. Dis. 2011, 204, (2), 200-208.

14. Alimonti, J.; Leung, A.; Jones, S.; Gren, J.; Qiu, X.; Fernando, L.; Balcewich, B.; Wong, G.; Ströher, U.; Grolla, A., Evaluation of transmission risks associated with in vivo replication of several high containment pathogens in a biosafety level 4 laboratory. Sci. Rep. 2014, 4.

15. Jaax, N.; Jahrling, P.; Geisbert, T.; Geisbert, J.; Steele, K.; McKee, K.; Nagley, D.; Johnson, E.; Jaax, G.; Peters, C., Transmission of Ebola virus (Zaire strain) to uninfected control monkeys in a biocontainment laboratory. The Lancet 1995, 346, (8991), 1669-1671.

16. Weingartl, H. M.; Embury-Hyatt, C.; Nfon, C.; Leung, A.; Smith, G.; Kobinger, G., Transmission of Ebola virus from pigs to non-human primates. Sci. Rep. 2012, 2.

17. Wolf, T.; Kann, G.; Becker, S.; Stephan, C.; Brodt, H.-R.; de Leuw, P.; Grünewald, T.; Vogl, T.; Kempf, V. A.; Keppler, O. T., Severe Ebola virus disease with vascular leakage and multiorgan failure: treatment of a patient in intensive care. The Lancet 2015, 385, (9976), 1428-1435.

18. Chertow, D. S.; Kleine, C.; Edwards, J. K.; Scaini, R.; Giuliani, R.; Sprecher, A., Ebola virus disease in West Africa-clinical manifestations and management. N. Engl. J. Med. 2014, 371, (22), 2054-2057.

19. Nguyen, J.; Smith, P. W., Nebraska Biocontainment Unit perspective on disposal of Ebola medical waste. Am. J. Infect. Control 2014, 30, 1-2.

20. World Health Organization, Interim infection prevention and control guidance for care of patients with suspected or confirmed filovirus haemorrhagic fever in health-care settings, with focus on Ebola. 2014. 
21. Bibby, K.; Casson, L. W.; Stachler, E.; Haas, C. N., Ebola virus persistence in the environment: State of the knowledge and research needs. Environ. Sci. Technol. Lett. 2014, 2, (1), 2-6.

22. Bibby, K.; Fischer, R. J.; Casson, L. W.; Stachler, E.; Haas, C. N.; Munster, V. J., Persistence of Ebola Virus in Sterilized Wastewater. Environ. Sci. Technol. Lett. 2015, 2, (9), 245-249.

23. Casanova, L. M.; Weaver, S. R., Inactivation of an enveloped surrogate virus in human sewage. Environ. Sci. Technol. Lett. 2015, 2, (3), 76-78.

24. Fischer, R.; Judson, S.; Miazgowicz, K.; Bushmaker, T.; Prescott, J.; Munster, V. J., Ebola virus stability on surfaces and in fluids in simulated outbreak environments. Emerg. Infect. Dis. 2015, 21, (7), 1243.

25. Ye, Y.; Ellenberg, R. M.; Graham, K. E.; Wigginton, K. R., Survivability, partitioning, and recovery of enveloped viruses in untreated municipal wastewater. Environ. Sci. Technol. 2016.

26. Johnson, D.; Lynch, R.; Marshall, C.; Mead, K.; Hirst, D., Aerosol generation by modern flush toilets. Aerosol Sci. Tech. 2013, 47, (9), 1047-1057.

27. Johnson, D. L.; Mead, K. R.; Lynch, R. A.; Hirst, D. V., Lifting the lid on toilet plume aerosol: a literature review with suggestions for future research. Am. J. Infect. Control 2013, 41, (3), 254-258.

28. Gerba, C. P.; Wallis, C.; Melnick, J. L., Microbiological hazards of household toilets: droplet production and the fate of residual organisms. J. Appl. Microbiol. 1975, $30,(2), 229-237$.

29. Best, E.; Sandoe, J.; Wilcox, M., Potential for aerosolization of Clostridium difficile after flushing toilets: the role of toilet lids in reducing environmental contamination risk. J. Hosp. Infect. 2012, 80, (1), 1-5.

30. Flores, G. E.; Bates, S. T.; Knights, D.; Lauber, C. L.; Stombaugh, J.; Knight, R.; Fierer, N., Microbial biogeography of public restroom surfaces. PLoS One. 2011, 6, (11), e28132.

31. Barker, J.; Jones, M., The potential spread of infection caused by aerosol contamination of surfaces after flushing a domestic toilet. J. Appl. Microbiol. 2005, 99, (2), 339-347.

32. Blair, M., Ceramic water closets. Osprey Publishing: 2000; Vol. 379.

33. Haas, D.; Unteregger, M.; Habib, J.; Galler, H.; Marth, E.; Reinthaler, F. F., Exposure to bioaerosol from sewage systems. Water Air Soil Poll. 2010, 207, (1-4), 4956. 
34. Visser, M.; Spaan, S.; Arts, H.; Smit, L.; Heederik, D., Influence of different cleaning practices on endotoxin exposure at sewage treatment plants. Ann. Occup. Hyg. 2006, 50, (7), 731-736.

35. Madsen, A. M.; Matthiesen, C. B., Exposure to aerosols during high-pressure cleaning and relationship with health effects. Annals of Agricultural and Environmental Medicine 2013, 20, (3).

36. Dutkiewicz, J.; Cholewa, G.; Sitkowska, J.; Krysinska-Traczyk, E.; Skorska, C.; Prazmo, Z., Exposure to bioaerosols in a municipal sewage treatment plant. Ann Agric Environ Med 2003, 10, 241-8.

37. Medema, G.; Wullings, B.; Roeleveld, P.; Van Der Kooij, D., Risk assessment of Legionella and enteric pathogens in sewage treatment works. Water Science and Technology: Water Supply 2004, 4, (2), 125-132.

38. Karra, S.; Katsivela, E., Microorganisms in bioaerosol emissions from wastewater treatment plants during summer at a Mediterranean site. Water Res. 2007, 41, (6), 1355 1365.

39. Li, L.; Han, Y.; Liu, J., Assessing genetic structure, diversity of bacterial aerosol from aeration system in an oxidation ditch wastewater treatment plant by culture methods and bio-molecular tools. Environ. Monit. Assess. 2013, 185, (1), 603-613.

40. Brandi, G.; Sisti, M.; Amagliani, G., Evaluation of the environmental impact of microbial aerosols generated by wastewater treatment plants utilizing different aeration systems. J. Appl. Microbiol. 2000, 88, (5), 845-852.

41. Bauer, H.; Fuerhacker, M.; Zibuschka, F.; Schmid, H.; Puxbaum, H., Bacteria and fungi in aerosols generated by two different types of wastewater treatment plants. Water Res. 2002, 36, (16), 3965-3970.

42. Uhrbrand, K.; Schultz, A. C.; Madsen, A. M., Exposure to airborne noroviruses and other bioaerosol components at a wastewater treatment plant in Denmark. Food Environ. Virol. 2011, 3, (3-4), 130-137.

43. Masclaux, F. G.; Hotz, P.; Gashi, D.; Savova-Bianchi, D.; Oppliger, A., Assessment of airborne virus contamination in wastewater treatment plants. Environ. Res. 2014, 133, 260-265. 


\section{Chapter 2. Aerosolization of Ebola Virus Surrogates in Wastewater Systems}

Kaisen Lin and Linsey C. Marr*

Department of Civil and Environmental Engineering, Virginia Tech, 418 Durham Hall, Blacksburg, Virginia 24061, United States

*Corresponding author

Mailing address: Department of Civil and Environmental Engineering, Virginia Tech, 418 Durham Hall, Blacksburg, Virginia 24061, United States

E-mail: $\underline{\text { lmarr@vt.edu }}$

Key words: Ebola, virus, bioaerosol, inhalation, wastewater

202 words in Abstract $+4,312$ word in Text +900 words in Figures +600 words in Table +65 words in Acknowledgements = Total 6,079 


\subsection{Abstract}

Recent studies have shown that Ebola virus can persist in wastewater, and the potential for the virus to be aerosolized and pose a risk of inhalation exposure has not been evaluated. We considered this risk for three wastewater systems: toilets, a lab-scale model of an aeration basin, and a lab-scale model of converging sewer pipes. We measured the aerosol size distribution generated by each system, spiked Ebola virus surrogates into each system, and determined the emission rate of viruses into the air. While the number of aerosols released ranged from $10^{5}$ to $10^{7}$ per flush from the toilets or per minute from the lab-scale models, the total volume of aerosols generated by these systems was $\sim 10^{-8}$ to $10^{-7} \mathrm{~mL}$ per flush or per minute in all cases. The Ebola virus surrogates MS2 and Phi6, spiked into toilets at an initial concentration of $10^{7} \mathrm{PFU} \mathrm{mL} \mathrm{m}^{-1}$, were not detected in air after flushing. Airborne concentrations of MS2 and Phi6 were $\sim 20 \mathrm{PFU} \mathrm{L}^{-1}$ and $\sim 0.1 \mathrm{PFU} \mathrm{L}^{-1}$, respectively, associated with the aeration basin and sewer models. This corresponds to emission rates of $547 \mathrm{PFU} \mathrm{min}{ }^{-1}$ and 3.8 PFU min ${ }^{-1}$ of MS2 and Phi6, respectively, for the aeration basin and $79 \mathrm{PFU} \mathrm{min}-1$ and $0.3 \mathrm{PFU} \mathrm{min}{ }^{-1}$ for the sewer model. Since information on the aerosolization of Ebola virus is quite limited, these emission rates can greatly help inform risk assessment of inhalation exposure to Ebola virus. 


\subsection{Introduction}

The Ebola virus disease (EVD) outbreak in West Africa that began in 2014 is the largest in history. It has caused 11,310 deaths as of June 2016 with a fatality rate of $53 \%$. The particular species causing the current outbreak, Zaire ebolavirus, is a member of the Filoviridae family. ${ }^{2,}{ }^{3}$ EVD is transmitted via direct contact with blood, body fluids, and objects contaminated with body fluids. ${ }^{4-6}$ Transmission is not thought to occur via air, water, or food, although in theory, aerosolization of blood and body fluids has the potential to lead to infection, as aerosol transmission has been demonstrated in nonhuman primates. ${ }^{7-}$ 10

EVD patients can produce large volumes of diarrhea that contain up to $10^{7}$ genome copies of the virus per milliliter. ${ }^{11-13}$ The World Health Organization recommends direct disposal of contaminated liquid waste into the sewage system without disinfection, ${ }^{14}$ but this guidance has raised concerns among environmental engineers because workers may come into close contact with wastewater, ${ }^{15}$ and as few as 10 infectious viral particles are sufficient to infect individuals. ${ }^{16-18}$ Recent studies indicate that Ebola virus and surrogates can survive for at least 1 day in wastewater. ${ }^{19,}{ }^{20}$ In addition, our research investigating the partitioning of Ebola virus surrogates among liquid, biosolids, and material surfaces demonstrated that at least $94 \%$ of virions partitioned into the liquid fraction. ${ }^{21}$ Thus, the vast majority of Ebola virus is likely to remain mobile in wastewater systems and maintain the potential to be aerosolized during certain processes.

Current risk assessments on inhalation exposure to Ebola virus in wastewater systems are based mainly on data from studies of bacteria, not viruses, conducted on toilets and wastewater treatment plants (WWTPs). ${ }^{22}$ Bacterial and fungi, including pathogenic 
ones, have been detected in the surrounding air, ${ }^{23-32}$ demonstrating that wastewater treatment processes have the potential to generate bioaerosols. However, few studies have focused on aerosolization of viruses in wastewater systems. ${ }^{33-35}$ Aerosolization of bacteria versus viruses could be significantly different due to dissimilarities in their size, structure, and concentration in wastewater. One important difference is that bacteria partition mainly to biosolids while viruses remain suspended in the liquid. ${ }^{21,}{ }^{36}$ Even fewer studies have focused on aerosolization from the wastewater collection system, ${ }^{30}$ yet processes like converging flows at pipe junctions and high-pressure cleaning have the potential to generate aerosols as well.

The goal of this research was to determine the potential for inhalation exposure to Ebola virus surrogates aerosolized during the regular operation and maintenance of wastewater systems. This study investigates flush toilets, a laboratory-scale aeration basin model, and a laboratory-scale sewer model. Specific objectives were to determine the size distribution of aerosols produced by each system and the emission rate of aerosolized Ebola virus surrogates spiked into the system. Results from this study can be used to assess the potential for inhalation exposure to Ebola virus for workers who may be in close proximity to contaminated wastewater.

\subsection{Materials and Methods}

Measurement of Aerosol Size Distribution in Model Systems. The size distribution of aerosols generated by flush toilets, a lab-scale aeration basin, and a lab-scale sewer model of converging pipes was measured inside of chambers customized specifically for this study. Aerosols were measured in triplicate experiments for each system using a scanning mobility particle sizer (TSI SMPS 3936) for particles 14-700 nm and an 
aerodynamic particle size spectrometer (TSI APS 3321) for particles 0.5-20 $\mu \mathrm{m}$. Results were combined using the TSI Data Merge program to generate a composite size distribution and corresponding fitted function using the default parameters. Prior to measurement, each chamber was flushed with air from a gas cylinder passed through a high-efficiency particulate air (HEPA) capsule to reduce the background particle concentration to below $50 \mathrm{~cm}^{-3}$.

Toilet-generated aerosols were characterized in a chamber fashioned by fitting a 46 $\mathrm{cm} \times 51 \mathrm{~cm}$ acrylic sheet over the toilet bowl. As shown in Figure S1, the sheet had a 15cm square cutout with a Tedlar bag sealed over it to allow the chamber volume to shrink as air was removed for sampling. The sheet supported a fan to promote mixing, three ports, and a temperature and humidity logger (OM-EL-USB-2-LDC). The initial chamber volume of $15 \mathrm{~L}$ was estimated by filling the bowl and bag with water.

Measurements were conducted on two commercial toilets in public restrooms at Virginia Tech. One had a Zurn Aquaflush automatic flushing mechanism, and the other had a Sloan Regal manual flushing mechanism. The acrylic sheet was taped to the bowl to ensure airtightness, and the chamber was flushed with HEPA-filtered air. The toilet was then flushed, and the aerosol size distribution was measured.

The lab-scale aeration basin, shown in Figure S2, consisted of a bubble disk diffuser (FlexAir, $22.9 \mathrm{~cm}$ diameter) placed at the bottom of an 11.4-L plastic basin. The basin was placed in a 240-L polyethylene glove bag (Sigma AtmosBag) that served as a chamber, supported by a PVC frame with dimensions of $86 \mathrm{~cm} \times 66 \mathrm{~cm} \times 61 \mathrm{~cm}$. Three portable mini-fans were used to promote mixing inside the chamber. The aerosol wall loss coefficient was determined experimentally to be $0.123 \mathrm{~min}^{-1}$ according to the same method 
described in our previous work. ${ }^{37}$ Additional details are provided in the Supporting Information.

The basin was filled with mixed liquor collected from the Christiansburg Wastewater Treatment Plant in Virginia, and the top of the diffuser was submerged $10 \mathrm{~cm}$ below the liquid surface. Table S1 shows the characteristics of the mixed liquor. HEPAfiltered air was then pumped through the diffuser at a flow rate of $10 \mathrm{~L} \mathrm{~min}^{-1}$, and excess air was vented to maintain a constant volume in the chamber. The system ran for $1 \mathrm{~h}$ to achieve steady-state conditions, confirmed by measurement of the aerosol concentration. The aerosol size distribution was then measured.

The lab-scale sewer model of converging pipes, shown in Figure S3, comprised a $35 \mathrm{~cm} \times 35 \mathrm{~cm}$ concrete model with two inflow open channels of diameter of $3.8 \mathrm{~cm}$ meeting at a $45^{\circ}$ angle and exiting via a single outflow open channel with the same diameter. The channels were connected to hoses, and a sump pump in an 18.9- $\mathrm{L}$ reservoir bucket circulated mixed liquor through the system. The flow velocity at the outlet was 0.4 $\mathrm{m} \mathrm{s}^{-1}$, and the Reynolds number was $1.8 \times 10^{4}$. The system was enclosed with a custom plastic lid, creating a 10-L above the channels, and two fans were used to promote mixing inside the chamber. The wall loss coefficient for this system was $0.229 \mathrm{~min}^{-1}$. The system was allowed to run for $30 \mathrm{~min}$ to ready steady state prior to measurement of the aerosol size distribution. HEPA-filtered air was used to make up that removed by the SMPS and APS during measurements.

Aerosolization of Ebola Virus Surrogates. Emission rates of two Ebola virus surrogates, the bacteriophages MS2 and Phi6, ${ }^{19-21}$ were determined in each wastewater system. MS2 (ATCC 15597-B1) is an unenveloped, single-stranded, RNA bacteriophage 
with Escherichia coli as its host. Phi6 (kindly provided by P. Turner of Yale University, New Haven, CT) is a lipid-enveloped, double-stranded, RNA bacteriophage with Pseudomonas syringae as its host. MS2 and Phi6 were propagated from stock suspensions according to established methods. ${ }^{38}$ The stocks had concentrations of $10^{9}-10^{11}$ plaqueforming units per milliliter (PFU mL-1). Briefly, $50 \mu \mathrm{L}$ of MS2 stock was mixed with 200 $\mu \mathrm{L}$ of overnight cultured E. coli and $4.75 \mathrm{~mL}$ of $\mathrm{LB}$ soft agar. The mixture was poured on LB plates and incubated at $37^{\circ} \mathrm{C}$ for $24 \mathrm{~h}$. Soft-agar layer was removed to a flask, and 3 $\mathrm{mL}$ of LB liquid medium was added per plate. The culture was then incubated with aeration at $37{ }^{\circ} \mathrm{C}$ for $4 \mathrm{~h}$. MS2 in suspension was harvested by low-speed centrifugation through $0.22 \mu \mathrm{m}$ filters at 6,000 rpm for $1 \mathrm{~min}$. For Phi6, P. syringae and TSB medium were used instead, and incubation took place at $25^{\circ} \mathrm{C}$.

MS2 and Phi6 were simultaneously spiked into wastewater to achieve a final

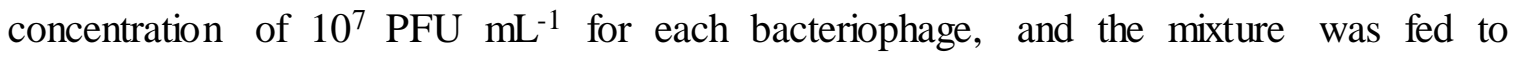
wastewater systems. No interference between MS2 and Phi6 was observed in a separate test. For toilets, $1 \mathrm{~L}$ of fresh anaerobically-digested sludge obtained from the same WWTP as the mixed liquor was poured into the toilet bowl to simulate the consistency of loose stool associated with EBOD. The chamber was flushed with HEPA-filtered air, and the toilet was then flushed. Aerosols were collected onto two $25 \mathrm{~mm}$ gelatin filters (SKC Inc. 225-9551) installed in stainless steel filter holders (Advantec 304500) for $20 \mathrm{~min}$ at a flow rate at $2 \mathrm{~L} \mathrm{~min}^{-1}$. During the sampling process, HEPA-filtered makeup air was provided to the chamber. After sample collection, one gelatin filter was dissolved in $3 \mathrm{~mL}$ of LB for analysis of MS2 and one was dissolved in TSB for analysis of Phi6. Ten-fold serial dilutions ranging from $1: 10$ to $1: 10^{-9}$ were prepared from the gelatin-filter-derived 
solutions. Aliquots of $50 \mu \mathrm{L}$ were used for bacteriophage quantification by plaque assay. The plates were incubated at $37^{\circ} \mathrm{C}$ and $25^{\circ} \mathrm{C}$ for MS2 and Phi6, respectively, for $24 \mathrm{~h}$. The number of plaques on each plate was counted, and bacteriophage concentrations were determined by multiplying the number by the dilution coefficient.

Similarly, the aeration basin and sewer model were filled with $10 \mathrm{~L}$ and $15 \mathrm{~L}$, respectively, of mixed liquor containing bacteriophage at a concentration of $10^{7} \mathrm{PFU} \mathrm{mL}-1$. As described previously, steady-state conditions were established. Aerosol samples were then collected onto gelatin filters, as described for the toilet experiments, at a point $20 \mathrm{~cm}$ above the center of the aeration basin and $10 \mathrm{~cm}$ above the junction of the sewer model. Excess air was vented in the aeration basin and makeup air was added to the sewer model chamber to maintain flow balance. The surfaces of both models were cleaned using $70 \%$ ethanol after each experiment.

Calculation of Emission Rates. Emission rates were calculated in units of PFU $\min ^{-1}$ for the aeration basin and sewer model. Based on mass balance, the airborne bacteriophage concentration in a well-mixed chamber can be described by Eq. 1. At steadystate conditions, the emission rates of Ebola virus surrogates can be determined from Eq. 2:

$$
\begin{aligned}
& \frac{d(c V)}{d t}=Q_{\text {in }} C_{\text {in }}-Q_{v} C_{\text {out }}-Q_{s} C_{\text {out }}+E-k C_{\text {out }} V \\
& E=-Q_{\text {in }} C_{\text {in }}+Q_{v} C_{\text {out }}+Q_{s} C_{\text {out }}+k C_{\text {out }} V
\end{aligned}
$$

where, $Q_{\text {in }}$ is the flow rate of particle-free air, $C_{\text {in }}$ is bacteriophage concentration in the particle-free air, which equals zero, $Q_{v}$ is the flow rate of excess air that is vented, $C_{\text {out }}$ is the airborne bacteriophage concentration, $Q_{S}$ is the flow rate of the air sampling pump, $E$ 
is the emission rate of bacteriophage from the wastewater system, $k$ is the aerosol wall loss coefficient, and $V$ is the chamber volume.

Because of the low volume of total aerosols produced by toilets and lack of detection of any viable bacteriophages in toilet air samples, the emission factor for toilets (i.e., number of PFUs aerosolized per flush) was expected to be negligible and thus was not determined using Eq. 1.

\subsection{Results}

Aerosol Size Distributions. Aerosol production by two commercial toilets containing water only, a lab-scale aeration basin containing mixed liquor, and a lab-scale model of converging sewer pipes containing mixed liquor was measured over the size range of $14 \mathrm{~nm}$ to $20 \mu \mathrm{m}$. Table 1 shows the mean and standard deviation of total aerosol number, total aerosol volume, and mode diameter from merged, fitted data from the SMPS and APS across three replicates for each system. The total number of aerosols generated by a toilet ranged from 1.7 to 1.9 million per flush, and the total volume of aerosols produced was on the order of $10^{-8} \mathrm{~mL}$. Figure 1(a) shows an example particle size distribution measured after flushing. The total aerosol concentration was low in this case, $87 \mathrm{~cm}^{-3}$, so the distribution is noisy. However, it is clear that a new mode below $100 \mathrm{~nm}$ was generated by flushing. Prior to flushing, the toilet chamber was filled with conditioned air from a gas cylinder that was drier than achieved after flushing. Relative humidity (RH) in the toilet bowl chamber rose from $\sim 85 \%$ to $\sim 90 \%$ after each flush, and the same was true for controls when no flushing occurred. Thus, it does not appear that evaporation contributed to low detection of aerosols. 
Table 1. Characteristics of aerosols generated per activity or per unit of time by flush toilets and lab-scale models of an aeration basin and converging sewer pipes.

\begin{tabular}{cccc}
\hline & Number & $\begin{array}{c}\text { Volume } \\
(\mathrm{mL})\end{array}$ & $\begin{array}{c}\text { Mode } \\
(\mathrm{nm})\end{array}$ \\
\hline $\begin{array}{c}\text { Toilet \#1 } \\
\text { (per flush) }\end{array}$ & $1.7 \pm 0.7 \times 10^{6}$ & $3.0 \pm 2.2 \times 10^{-8}$ & $14 \pm 4$ \\
$\begin{array}{c}\text { Toilet \#2 } \\
\text { (per flush) }\end{array}$ & $1.9 \pm 0.2 \times 10^{6}$ & $1.2 \pm 1.0 \times 10^{-8}$ & $15 \pm 8$ \\
$\begin{array}{c}\text { Aeration basin } \\
\left(\text { min }^{-1}\right)\end{array}$ & $9.5 \pm 1.2 \times 10^{6}$ & $1.9 \pm 0.1 \times 10^{-7}$ & $60 \pm 5$ \\
$\begin{array}{c}\text { Converging pipes } \\
\left(\text { min }^{-1}\right)\end{array}$ & $2.5 \pm 0.3 \times 10^{5}$ & $2.6 \pm 0.1 \times 10^{-8}$ & $146 \pm 16$ \\
\hline
\end{tabular}

The aeration basin produced aerosols at a rate of $9.5 \times 10^{6} \mathrm{~min}^{-1}$ and $1.9 \times 10^{-7} \mathrm{~mL}$ $\min ^{-1}$ in terms of total number and volume, respectively. The total number concentration inside the chamber was $275 \mathrm{~cm}^{-3}$ on average, which was about twice that in the toilet chamber $\left(148 \mathrm{~cm}^{-3}\right)$. Figure 1(b) shows an example aerosol size distribution, which was unimodal and centered at $63 \mathrm{~nm}$, indicating that the aeration basin produced larger aerosols than did the flush toilets.

The converging sewer pipes produced aerosols at a rate of $2.5 \times 10^{5} \mathrm{~min}^{-1}$ and 2.6 $\times 10^{-8} \mathrm{~mL} \mathrm{~min}^{-1}$ in terms of total number and volume, respectively. This rate was 38 times lower than produced by the aeration basin in terms of number, and 7 times lower in terms of volume. The example size distribution shown in Figure 1(c) appeared to be trimodal and included a small, broad peak near $1000 \mathrm{~nm}$, or $1 \mu \mathrm{m}$. The sewer was the only one among the three wastewater systems to generate these larger aerosols, which help account for the 
larger difference in volume of aerosols than in number of aerosols generated compared to the aeration basin.

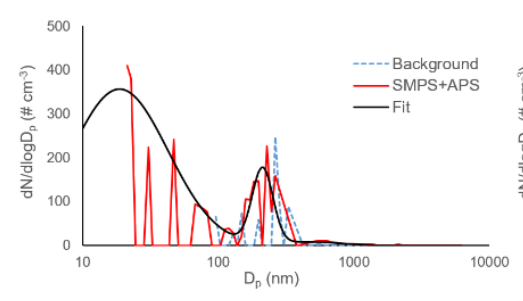

(a)

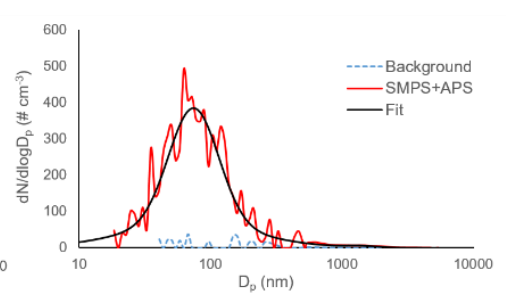

(b)

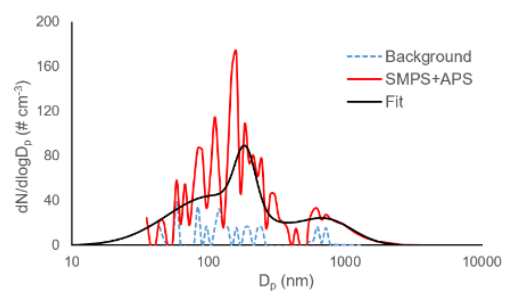

(c)

Figure 1. Examples of aerosol size distributions generated by wastewater systems: (a) flush toilet; (b) aeration basin; (c) converging sewer pipes. The red curve represents the composite data from SMPS and APS. The black curve represents the fit to the composite data.

Virus Concentrations. Figure 2 and Figure 3 show the concentrations of Ebola virus surrogates in the chamber air and mixed liquor in the aeration basin and converging sewer pipes model for MS2 and Phi6, respectively. The average airborne concentrations of MS2 were 15 and $21 \mathrm{PFU} \mathrm{L}^{-1}$ in the aeration basin and converging sewer pipes model, respectively. Airborne concentrations of MS2 in the aeration basin model were slightly higher than in the model of converging sewer pipes, although this result is contingent upon the size of the experimental chamber: $200 \mathrm{~L}$ for the aeration basin and $10 \mathrm{~L}$ for the sewer pipes. Over the course of the experiments, which lasted 2-3 hours each, the MS2 concentration in the mixed liquor decreased by $\sim 0.1 \log _{10}$ to an average of $7.3 \times 10^{6} \mathrm{PFU}$ $\mathrm{mL}^{-1}$ in the aeration basin and $8.5 \times 10^{6} \mathrm{PFU} \mathrm{mL}^{-1}$ in the converging sewer pipe model.

Compared to MS2, the airborne concentration Phi6 was much lower, only $\sim 0.1 \mathrm{PFU}$ $\mathrm{L}^{-1}$ in both models. Furthermore, the concentration of Phi6 decreased substantially in the 
mixed liquor over the course of the experiment, by $0.8 \log _{10}$ in the aeration basin and 2.6 $\log _{10}$ in the converging sewer pipes model.

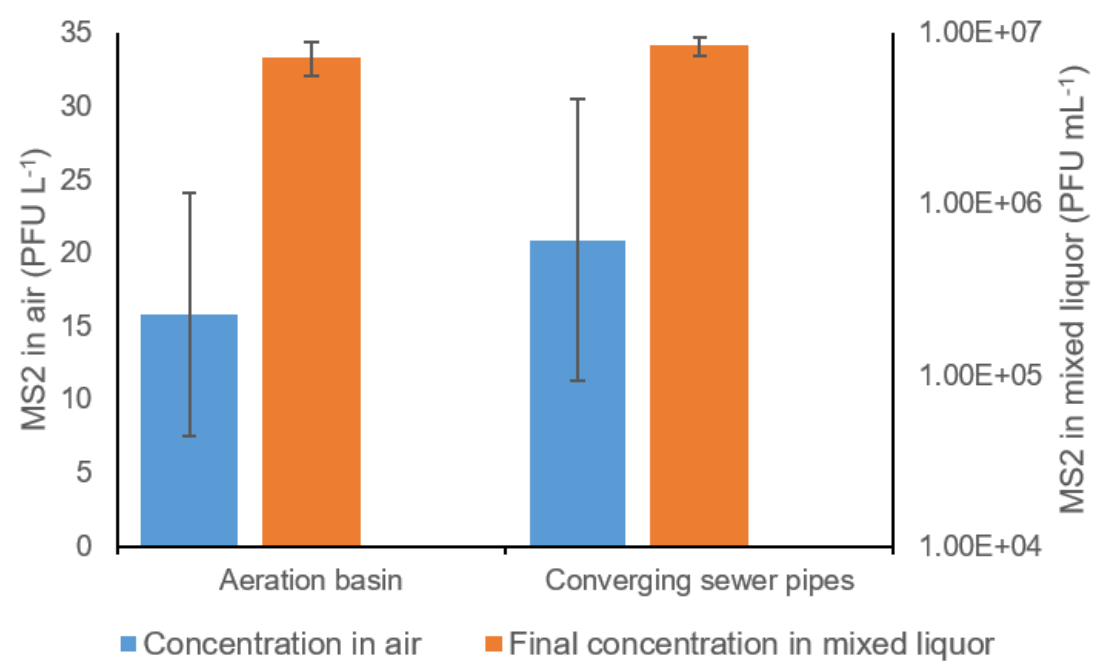

Figure 2. MS2 concentrations in air and corresponding mixed liquor from which they were generated in lab-scale models of an aeration basin and converging sewer pipes with MS2 at an initial concentration in mixed liquor of $10^{7} \mathrm{PFU} \mathrm{mL}^{-1}$.

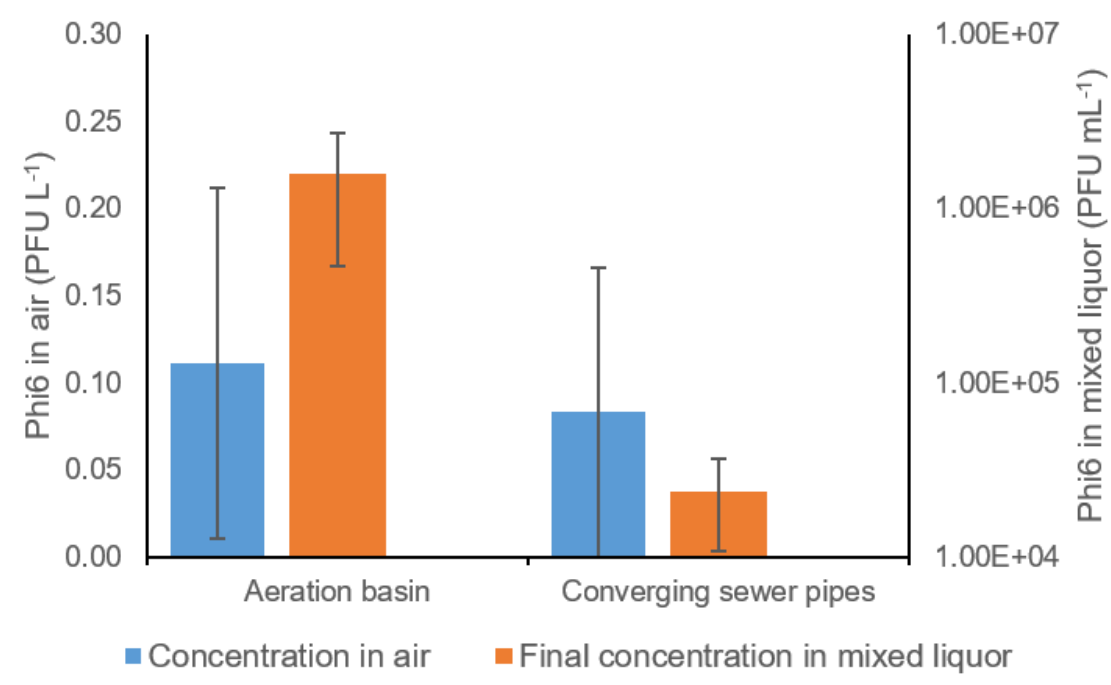

Figure 3. Phi6 concentrations in air and corresponding mixed liquor from which they were generated in lab-scale models of an aeration basin and converging sewer pipes with Phi6 at an initial concentration in mixed liquor of $10^{7} \mathrm{PFU} \mathrm{mL}^{-1}$. 
Virus Emission Rates. Table 2 presents the emission rates of aerosolized Ebola virus surrogates from the wastewater systems. Airborne MS2 and Phi6 were not detected with the toilets. Between the two other systems, the highest emission rate was $547 \pm 287$ PFU $\min ^{-1}$ for MS2 in the aeration basin, and the lowest emission rate was $0.3 \pm 0.3 \mathrm{PFU}$ $\min ^{-1}$ for Phi6 in the converging sewer pipes. In general, the emission rate was at least 100 times higher for MS2 compared to Phi6, and the aeration basin emitted both surrogates at a rate 10 times higher than did the converging sewer pipes.

Table 2. Emission rates of Ebola virus surrogates by toilets and lab-scale models of an aeration basin and converging sewer pipes

\begin{tabular}{cccc}
\hline Surrogates & $\begin{array}{c}\text { Toilets } \\
(\mathrm{PFU} \text { per flush })\end{array}$ & $\begin{array}{c}\text { Aeration basin } \\
\left(\mathrm{PFU} \text { min }^{-1}\right)\end{array}$ & $\begin{array}{c}\text { Converging pipes } \\
\left(\mathrm{PFU} \mathrm{m^{-1 }}\right)\end{array}$ \\
\hline MS2 & not detected & $547 \pm 287$ & $79 \pm 36$ \\
Phi6 & not detected & $3.8 \pm 3.5$ & $0.3 \pm 0.3$ \\
\hline
\end{tabular}

\subsection{Discussion}

While toilets generate a large number of aerosols, the total volume of liquid aerosolized is very small, so the chance of aerosolizing viruses upon flushing is expected to be low. For the toilets investigated in this study, the total number of aerosols generated per flush is an order of magnitude higher than reported in previous studies. ${ }^{31}$ This difference can be explained by our use of a scanning mobility particle sizer that is able to detect smaller aerosols compared to optical methods that have a lower limit of $0.3 \mu \mathrm{m}$ used in prior studies. The total volume of aerosols produced per flush is low enough that not every flush 
of contaminated liquid waste in a toilet would be expected to aerosolize Ebola virus if the virus is not preferentially aerosolized compared to the bulk liquid. Virus concentrations of $\sim 10^{7}$ genome copies $\mathrm{mL}^{-1}$ have been reported in the diarrhea of patients with Ebola virus disease. ${ }^{13}$ Even if the virus were not diluted in the toilet bowl, the average number of virions aerosolized per flush would be $\sim 0.1$ (i.e., the product of $10^{7}$ genome copies $\mathrm{mL}^{-1}$ and the $\sim 10^{-8} \mathrm{~mL}$ of aerosol volume generated by flushing). It is possible that aerosols evaporated during our experiments and that the actual amount of liquid initially aerosolized was higher, but RH remained high $(\sim 90 \%)$ and if aerosols did evaporate, they would have left behind solid impurities that are present in all but the purest water. The evaporation process is expected to be very fast, less than $1 \mathrm{~s},{ }^{39}$ so observing it would require different detection methods.

While several studies have investigated aerosolization of bacteria from toilets, ${ }^{23}$, 25, 26, 29 only one to our knowledge has focused on viruses; given an initial MS2 concentration of $10^{7} \mathrm{PFU} \mathrm{mL} \mathrm{m}^{-1}$ in the toilet bowl water, airborne MS2 was detected at a concentration of $2.4 \mathrm{PFU} \mathrm{L}^{-1}$ at a location $30 \mathrm{~cm}$ in front of the toilet and $20 \mathrm{~cm}$ above the toilet seat immediately after flushing. ${ }^{23}$ A different carrier of the inoculum and different sampling method in that study compared to ours could account for the different observations (i.e., we did not detect any viable MS2). Our findings suggest that the potential for inhalation exposure to Ebola virus surrogates aerosolized by flushing toilets is low. This result does not negate the possibility of infection by contact with large droplets that splash out of the toilet onto the floor, walls, toilet itself, and other nearby surfaces.

This study is the first to investigate the aerosolization of viruses from an aeration basin in terms of viability. While other studies have reported concentrations of airborne 
bacteria around WWTPs, ${ }^{24,27,30,32}$ fewer have focused on airborne viruses. ${ }^{34,}{ }^{40}$ Our results show that viable virus can be aerosolized from an aeration basin. By reporting results not just as concentrations but also as emission rates, they can be extended to other scenarios. For example, if the aerosolization rate is linear with number of diffusers in a system, then a multiplicative factor can be applied to estimate virus emission rates from larger systems. Logically, the amount of virus aerosolized should depend on its concentration in wastewater. This work is one of the first to quantify virus concentration in both air and wastewater simultaneously. ${ }^{40}$ These data can be used to develop an aerosolization ratio (i.e., concentration in air / concentration in stock), or what others have called a partitioning constant, 41,42 although such a ratio is specific to the characteristics of the particular system in question. The ratios in our aeration basin model were on the order of $10^{-9}$ and $10^{-11}$ for MS2 and Phi6, respectively. Of greater interest may be a comparison of aerosol volume and number of virions. The ratio of virus emission rate (Table 2) to aerosol volume emission rate (Table 1) represents the concentration of virions in the aerosols themselves. For MS2, these ratios are $2.9 \times 10^{9} \mathrm{PFU} \mathrm{mL}^{-1}$ and $3.0 \times 10^{9} \mathrm{PFU} \mathrm{mL}^{-1}$ for the aeration basin and sewer model, respectively. The concentration of MS2 in the mixed liquor that served as the source of these aerosols was only $10^{7} \mathrm{PFU} \mathrm{mL}{ }^{-1}$, indicating that MS2 is enriched in the aerosols. It is possible that, particularly with aerosol generation by bubble bursting as in the aeration basin, MS2 partitions preferentially to the air-liquid interface. For Phi6, the ratios of $2.0 \times 10^{7} \mathrm{PFU} \mathrm{mL}^{-1}$ and $1.2 \times 10^{7} \mathrm{PFU} \mathrm{mL}^{-1}$ for the aeration basin and sewer model, respectively, are similar to the initial concentration in the mixed liquor, although if inactivation is taken into account, then the ratios could be indicative of 
enrichment of Phi6 in aerosols, too. Clearly, further study is needed on the topic of enrichment of microorganisms in aerosols generated from a liquid source.

Another quantity of interest is the fraction of virus that is aerosolized from the wastewater per unit time. In this study, the fraction is on the order of $10^{-9} \mathrm{~min}^{-1}$ and $10^{-11}$ $\min ^{-1}$ for MS2 and Phi6, respectively. These results apply for an aeration basin with a single diffuser at a $10 \mathrm{~cm}$ below the water. Although the ratios seem extremely low, the number of aerosolized viruses will be large since millions gallons of wastewater are treated every day. Future studies should determine whether the aerosol generate rate scales linearly with number of diffusers and how it varies with depth below the water and with wastewater characteristics.

Data on aerosol production in wastewater collection systems are limited. Studies of oceans and lakes have shown that aerosols may be produced by bubble bursting and breaking waves, ${ }^{43,44}$ and such processes may be active, though at smaller scale, in a sewer system. To the best of our knowledge, this study is the first to investigate the aerosol size distribution produced by converging sewer pipes. Our results show that converging flows can aerosolize Ebola virus surrogates. The emission rate is lower compared to the aeration basin, but the confined geometry of a sewer system may lead to higher concentrations and higher inhalation exposure. At a concentration of $0.1 \mathrm{PFU} \mathrm{L}^{-1}$ (Phi6 in Figure 3) and EPA's default inhalation rate of $20 \mathrm{~m}^{3}$ day $^{-1}$, a worker could be exposed to 10 virions, the amount thought necessary to cause infection, in just over $7 \mathrm{~min}$. The effects of flow rate, pipe size, and wastewater composition on aerosol generation are not yet known. Another concern that is not addressed by this study is high-pressure cleaning, which is likely to generate aerosols, ${ }^{30}$ although such activity can be postponed until after an Ebola threat has passed. 
A decrease in the concentration of Ebola virus surrogates in mixed liquor was observed in this study. Such loss is usually attributable to biological inactivation and physical absorption. The majority of loss is likely due to biological inactivation because physical adsorption has been shown to be minimal for enteric viruses. ${ }^{45} \mathrm{~A} \mathrm{~T}_{90}$ value (i.e., time to reach $90 \%$ inactivation) of 121 hours MS2 in unpasteurized wastewater at $25{ }^{\circ} \mathrm{C}$ was reported in a previous study. ${ }^{46}$ The decrease in Phi6 concentration in the converging sewer pipes model is larger compared to that in earlier studies on the persistence of Phi6 in wastewater and the inactivation of Ebola virus in sterilized wastewater. ${ }^{19}$ The difference may be due to the effect of heat inactivation inside the sump pump, used for flow circulation in the sewer model, as Phi6 is believed to be more sensitive to higher temperature. ${ }^{20}$ The finding that heat inactivation only applies to Phi6 is consistent with the general finding of greater susceptibility of enveloped viruses to inactivation. ${ }^{46}$

The large difference in airborne concentrations of MS2 and Phi6, a factor of $>100$, in both the aeration basin and sewer model can be attributed to two causes. First, their different inactivation and absorption rates results in different final concentrations in the mixed liquor even though they were spiked at the same initial concentration. Thus, over time, relatively more MS2 was available for aerosolization. The other reason is that the aerosolization efficiencies of MS2 and Phi6 differ. In a separate experiment (described in the SI), we compared the aerosolization efficiencies of MS2 and Phi6 from a nebulizer. The result indicated that MS2 was aerosolized 2 times as efficiently compared to Phi6.

This study provides new information about the potential for aerosolization of Ebola virus surrogates from wastewater systems, but it has several limitations. First, this study necessarily employs surrogate viruses whose aerosolization potential may differ from that 
of Ebola virus. Phi6 is thought to be the more relevant surrogate because, like Ebola virus, it is enveloped, and surface properties are expected to affect partitioning at the air-water interface. Additionally, the icosahedral morphology of Phi6 differs considerably from the filamentous morphology of Ebola virus, and effect of such morphological and size differences on potential for aerosolization is not known. Second, although considerable care was taken to design lab-scale models with realistic features, the models do not represent a full-scale aeration basin and sewer system. Scaling factors, operational variables, and environmental factors will influence aerosolization of Ebola virus in real systems. Complementary studies in real systems using native viruses or spiked tracers would help address this limitation. Third, how aerosolization varies with liquid composition is not known. Factors such as fluid viscosity and surfactant content may affect the generation of aerosols from liquid. Fourth, the concentration of spiked surrogates is higher than Ebola virus is likely to be found in wastewater. Based on the reported number of genome copies of Ebola virus in patients' diarrhea and the dilution rate of excrement in wastewater systems, recent studies applied surrogates with concentrations of $10^{2}$ to $10^{7}$ PFU $\mathrm{mL}^{-1}$, with the upper end being a worst-case scenario. ${ }^{13,}{ }^{19,47}$ However, the effect of virus concentration in wastewater on its aerosolization is unknown. Because of these limitations, further investigation is needed to pursue a more accurate estimation of the potential for aerosolization of Ebola virus in wastewater systems.

These results suggest that flush toilets, aeration basins, and converging sewer pipes can aerosolize Ebola virus in wastewater. The results of this study add to the database of bacteria and virus concentrations in air around wastewater systems, and the emission factors can be used to predict virus concentrations in a variety of scenarios, such as 
outdoors using an atmospheric dispersion model or in an enclosed system whose air is assumed to be well mixed; both models would require an emission rate. Although the reported concentrations of Ebola virus surrogates in ambient air are low, they are suffic ient to lead to inhalation exposure that would be of concern for Ebola virus. Aerosolization from toilets appears to present the lowest risk, while aerosolization in sewer systems and at WWTPs may be a concern if infectious virus is present. The results in our study will be particularly important for risk assessment on the potential for exposure to EBOV for sewer workers who work closely with contaminated wastewater.

\subsection{Acknowledgements}

This research was supported by the National Science Foundation under a RAPID award (CBET-1509493), and the Water Environment Research Foundation (2C15). Virginia Tech's Institute for Critical Technology and Applied Science provided laboratory resources. A. Pruden provided laboratory resources and helpful discussions. We thank M. Lee, K. Hughes, L. Buttling, M. Chandler, and employees at the Christiansburg Wastewater Treatment Plant for assistance with this research.

\subsection{Supporting Information}

Table of the characteristics of mixed liquor and anaerobically-digested sludge; details about wall loss coefficients; figure of wall loss coefficient curve; photos of experimental setup; description of experiment on aerosolization of Ebola virus surrogates by nebulizer; description of experiment on mutual interference between MS2 and Phi6; 
Table S1. Characteristics of mixed liquor and anaerobically-digested sludge

\begin{tabular}{|c|c|c|c|c|}
\hline Sample type & System & $\mathrm{pH}$ & $\begin{array}{l}\text { Total suspended } \\
\text { solids (mg L-1) }\end{array}$ & $\begin{array}{l}\text { Volatile suspended } \\
\text { solids }\left(\mathrm{mg} \mathrm{L}^{-1}\right)\end{array}$ \\
\hline $\begin{array}{l}\text { Anaerobically- } \\
\text { digested sludge }\end{array}$ & Flush toilet & 7.3 & 17,260 & 13,180 \\
\hline Mixed liquor & Aeration basin model & 7.0 & 1,760 & 1,620 \\
\hline Mixed liquor & Converging sewer pipes model & 7.1 & 1,920 & 1,570 \\
\hline
\end{tabular}




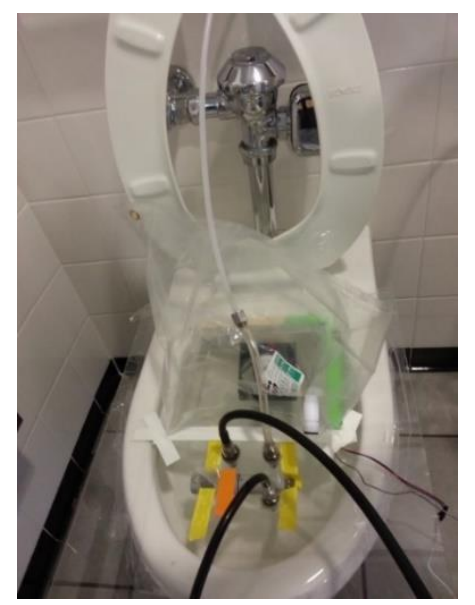

Figure S1. Experimental setup for measurement of toilet-generated aerosols.

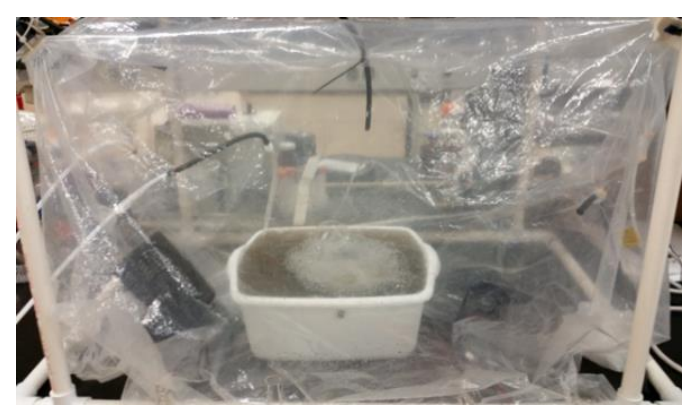

Figure S2. Lab-scale model of aeration basin.

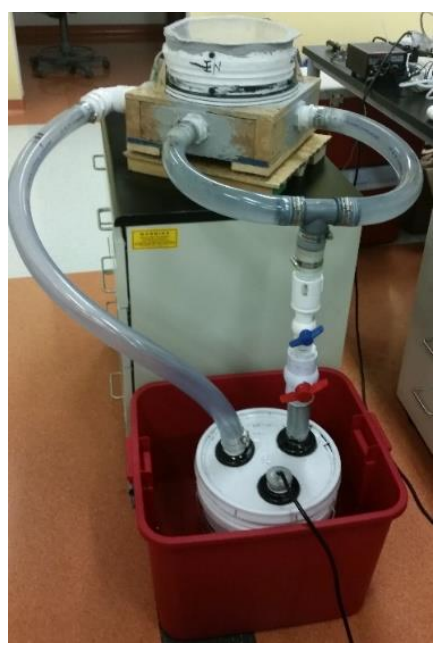

Figure S3. Lab-scale model of converging sewer pipes. 


\section{Wall loss coefficients}

Determination of wall loss coefficients followed the procedure described in our previous work. ${ }^{1}$ In brief, we ran the aeration basin and sewer model until they reached steady-state conditions. Then we stopped the aerosolization (i.e., turned off the diffuser in the aeration basin and halted liquid flow in the sewer model) and measured the number and volume concentration of aerosol in air chamber over time with SMPS and APS. HEPAfiltered air was added to the chamber to maintain a flow balance.

We assumed that wall loss follows first-order decay process and calculated the wall loss coefficient for total aerosol volume, the metric of greatest interest, according to the fitted equation. 


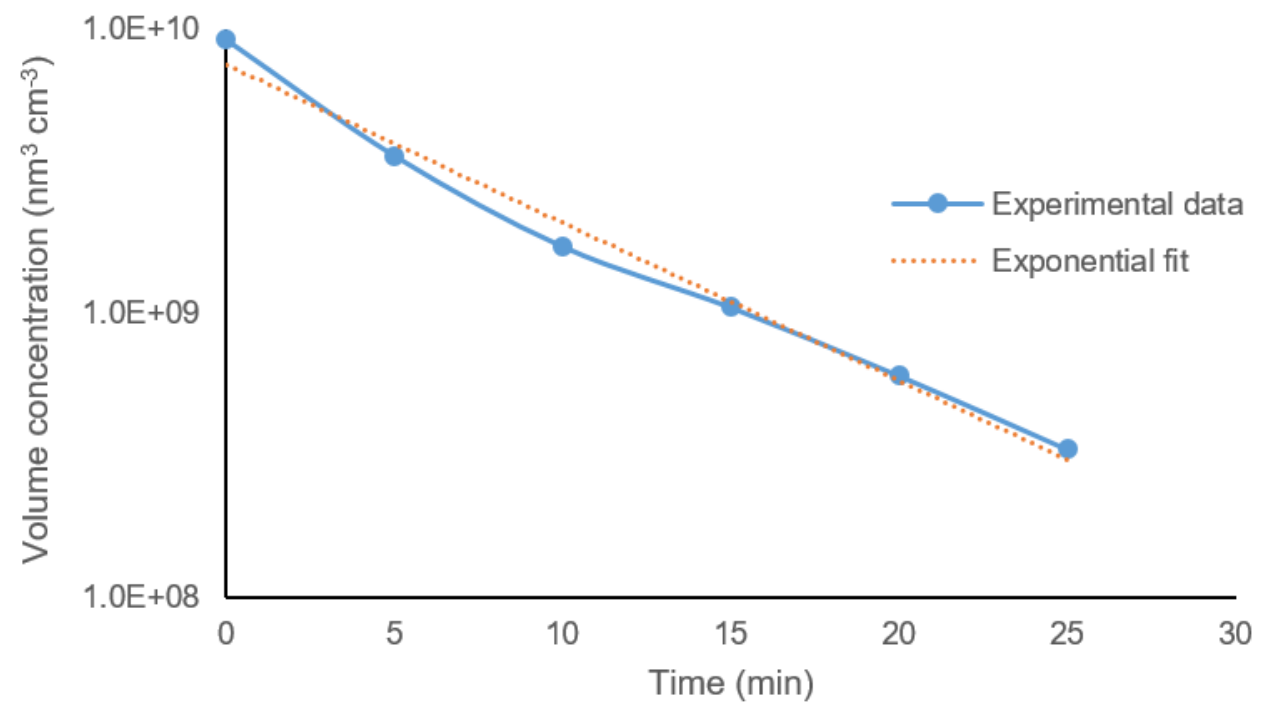

Figure S4. Wall loss coefficient curve for aeration basin model

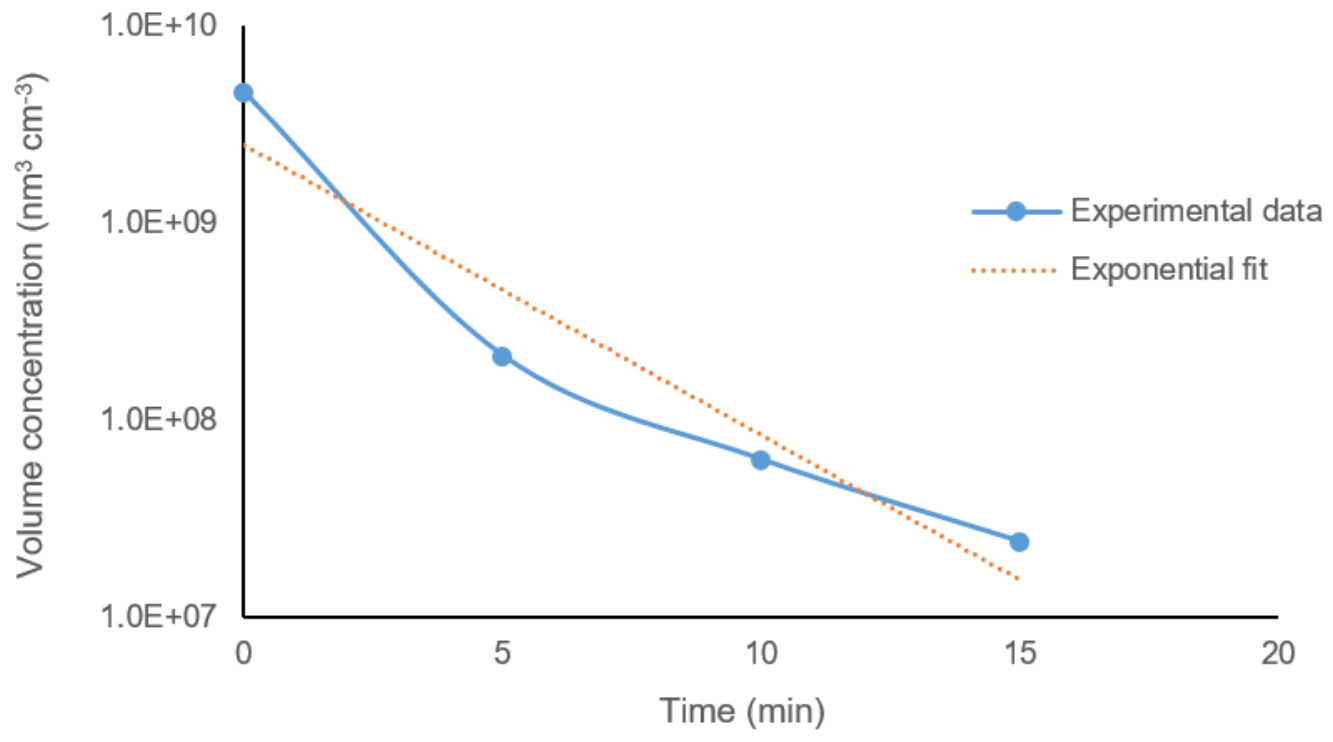

Figure S5. Wall loss coefficient curve for converging sewer pipes model 


\section{Mutual interference of surrogate viruses}

We tested whether the Ebola virus surrogates used in this study could infect each other's host and affect experimental results when they were spiked simultaneously into mixed liquor or anaerobically digested sludge. We performed plaque assays on Phi6 and MS2, but with the opposite host bacteria (i.e., Phi6 infects E.coli and MS2 infects $P$. syringae) at their respective growth temperatures. No Phi6 plaques were observed on $E$. coli plates and no MS2 plaques were observed on $P$. syringae plates. The results confirmed that there should be no concern about mutual interference when the two bacteriophages were spiked simultaneously into the same matrix. 


\section{Aerosolization of MS2 and Phi6 by Collison nebulizer}

In order to compare the aerosolization efficiencies of MS2 and Phi6, we conducted a separate experiment with a 1-Jet BGI Collison nebulizer. In this experiment, we added $20 \mathrm{~mL}$ of sterilized pure water with surrogates spiked at a concentration of $10^{7} \mathrm{PFU} \mathrm{mL}-1$ into the nebulizer. We placed the nebulizer in the chamber that was used for the aeration basin. We started to generate aerosols at a controlled air flow rate of $5 \mathrm{~L} \mathrm{~min}^{-1}$. Once steady state was reached, we collected air samples using the same method described in the Materials and Methods section and applied plaque assay for quantification of viable virus. We calculated and compared the aerosolization efficiency, which is the ratio between the concentration of virus in air and the concentration in liquid suspension at the end of the experiment. The result showed that the aerosolization efficiencies for MS2 and Phi6 were $8.6 \times 10^{-8}$ and $4.6 \times 10^{-8}$, respectively. Thus, MS2 was aerosolized 1.89 times as efficie ntly compared to Phi6.

\section{References}

1. CDC 2014 Ebola Outbreak in West Africa - Case Counts http://www.cdc.gov/vhf/ebola/outbreaks/2014-west-africa/case-counts.html

2. Pourrut, X.; Kumulungui, B.; Wittmann, T.; Moussavou, G.; Délicat, A.; Yaba, P.; Nkoghe, D.; Gonzalez, J.-P.; Leroy, E. M., The natural history of Ebola virus in Africa. Microbes Infect. 2005, 7, (7-8), 1005-1014.

3. Team, W. E. R., Ebola virus disease in West Africa-the first 9 months of the epidemic and forward projections. N. Engl. J. Med. 2014, 371, (16), 1481-95.

4. Bausch, D. G.; Towner, J. S.; Dowell, S. F.; Kaducu, F.; Lukwiya, M.; Sanchez, A.; Nichol, S. T.; Ksiazek, T. G.; Rollin, P. E., Assessment of the risk of Ebola virus transmission from bodily fluids and fomites. J. Infect. Dis. 2007, 196, (Supplement 2), S142-S147.

5. CDC Ebola Transmission. http:/www.cdc.gov/vhf/ebola/transmission/

6. Edmunds, K. L.; Elrahman, S. A.; Bell, D. J.; Brainard, J.; Dervisevic, S.; Fedha, T. P.; Few, R.; Howard, G.; Lake, I.; Maes, P., Recommendations for dealing with waste 
contaminated with Ebola virus: a Hazard Analys is of Critical Control Points approach. Bull. W.H.O 2016, 94, (6), 424-432.

7. Alimonti, J.; Leung, A.; Jones, S.; Gren, J.; Qiu, X.; Fernando, L.; Balcewich, B.; Wong, G.; Ströher, U.; Grolla, A., Evaluation of transmission risks associated with in vivo replication of several high containment pathogens in a biosafety level 4 laboratory. Sci. Rep. 2014, 4.

8. Jaax, N.; Jahrling, P.; Geisbert, T.; Geisbert, J.; Steele, K.; McKee, K.; Nagley, D.; Johnson, E.; Jaax, G.; Peters, C., Transmission of Ebola virus (Zaire strain) to uninfected control monkeys in a biocontainment laboratory. The Lancet 1995, 346, (8991), 1669-1671.

9. Kobinger, G. P.; Leung, A.; Neufeld, J.; Richardson, J. S.; Falzarano, D.; Smith, G.; Tierney, K.; Patel, A.; Weingartl, H. M., Replication, pathogenicity, shedding, and transmission of Zaire ebolavirus in pigs. J. Infect. Dis. 2011, 204, (2), 200-208.

10. Weingartl, H. M.; Embury-Hyatt, C.; Nfon, C.; Leung, A.; Smith, G.; Kobinger, G., Transmission of Ebola virus from pigs to non-human primates. Sci. Rep. 2012, 2.

11. Chertow, D. S.; Kleine, C.; Edwards, J. K.; Scaini, R.; Giuliani, R.; Sprecher, A., Ebola virus disease in West Africa-clinical manifestations and management. N. Engl. J. Med. 2014, 371, (22), 2054-2057.

12. Nguyen, J.; Smith, P. W., Nebraska Biocontainment Unit perspective on disposal of Ebola medical waste. Am. J. Infect. Control 2014, 30, 1-2.

13. Wolf, T.; Kann, G.; Becker, S.; Stephan, C.; Brodt, H.-R.; de Leuw, P.; Grünewald, T.; Vogl, T.; Kempf, V. A.; Keppler, O. T., Severe Ebola virus disease with vascular leakage and multiorgan failure: treatment of a patient in intensive care. The Lancet 2015, 385, (9976), 1428-1435.

14. World Health Organization, Interim infection prevention and control guidance for care of patients with suspected or confirmed filovirus haemorrhagic fever in health-care settings, with focus on Ebola. 2014.

15. Bibby, K.; Casson, L. W.; Stachler, E.; Haas, C. N., Ebola virus persistence in the environment: State of the knowledge and research needs. Environ Sci Technol Lett. 2014, $2,(1), 2-6$.

16. Franz, D. R.; Jahrling, P. B.; Friedlander, A. M.; McClain, D. J.; Hoover, D. L.; Bryne, W. R.; Pavlin, J. A.; Christopher, G. W.; Eitzen, E. M., Clinical recognition and management of patients exposed to biological warfare agents. Jama 1997, 278, (5), 399411.

17. Jelden, K. C.; Gibbs, S. G.; Smith, P. W.; Schwedhelm, M. M.; Iwen, P. C.; Beam, E. L.; Hayes, A. K.; Marion, N.; Kratochvil, C. J.; Boulter, K. C., Nebraska Biocontainment Unit patient discharge and environmental decontamination after Ebola care. Am. J. Infect. Control 2015, 43, (3), 203-205. 
18. Johnson, E.; Jaax, N.; White, J.; Jahrling, P., Lethal experimental infections of rhesus monkeys by aerosolized Ebola virus. Int. J. Exp. Pathol. 1995, 76, (4), 227.

19. Bibby, K.; Fischer, R. J.; Casson, L. W.; Stachler, E.; Haas, C. N.; Munster, V. J., Persistence of Ebola Virus in Sterilized Wastewater. Environ Sci Technol Lett. 2015, 2, (9), 245-249.

20. Casanova, L. M.; Weaver, S. R., Inactivation of an enveloped surrogate virus in human sewage. Environ Sci Technol Lett. 2015, 2, (3), 76-78.

21. Titcombe Lee, M.; Pruden, A.; Marr, L. C., Partitioning of Viruses in Wastewater Systems and Potential for Aerosolization. Environ Sci Technol Lett. 2016, 3, (5), 210215.

22. Haas, C. N. Risks from Ebola discharge from hospitals to sewer workers, Water Environment \& Resuse Foundation report number WERF4C15PDF; 2016.

23. Barker, J.; Jones, M., The potential spread of infection caused by aerosol contamination of surfaces after flushing a domestic toilet. J. Appl. Microbiol. 2005, 99, (2), 339-347.

24. Bauer, H.; Fuerhacker, M.; Zibuschka, F.; Schmid, H.; Puxbaum, H., Bacteria and fungi in aerosols generated by two different types of wastewater treatment plants. Water Res. 2002, 36, (16), 3965-3970.

25. Best, E.; Sandoe, J.; Wilcox, M., Potential for aerosolization of Clostridium difficile after flushing toilets: the role of toilet lids in reducing environmental contamination risk. J. Hosp. Infect. 2012, 80, (1), 1-5.

26. Blair, M., Ceramic water closets. Osprey Publishing: 2000; Vol. 379.

27. Brandi, G.; Sisti, M.; Amagliani, G., Evaluation of the environmental impact of microbial aerosols generated by wastewater treatment plants utilizing different aeration systems. J. Appl. Microbiol. 2000, 88, (5), 845-852.

28. Flores, G. E.; Bates, S. T.; Knights, D.; Lauber, C. L.; Stombaugh, J.; Knight, R.; Fierer, N., Microbial biogeography of public restroom surfaces. PLoS One. 2011, 6, (11), e28132.

29. Gerba, C. P.; Wallis, C.; Melnick, J. L., Microbiological hazards of household toilets: droplet production and the fate of residual organisms. J. Appl. Microbiol. 1975, 30, (2), 229-237.

30. Haas, D.; Unteregger, M.; Habib, J.; Galler, H.; Marth, E.; Reinthaler, F. F., Exposure to bioaerosol from sewage systems. Water Air Soil Poll. 2010, 207, (1-4), 4956.

31. Johnson, D.; Lynch, R.; Marshall, C.; Mead, K.; Hirst, D., Aerosol generation by modern flush toilets. Aerosol Sci. Tech. 2013, 47, (9), 1047-1057. 
32. Li, L.; Han, Y.; Liu, J., Assessing genetic structure, diversity of bacterial aerosol from aeration system in an oxidation ditch wastewater treatment plant by culture methods and bio-molecular tools. Environ. Monit. Assess. 2013, 185, (1), 603-613.

33. Heinonen-Tanski, H.; Reponen, T.; Koivunen, J., Airborne enteric coliphages and bacteria in sewage treatment plants. Water Res. 2009, 43, (9), 2558-2566.

34. Masclaux, F. G.; Hotz, P.; Gashi, D.; Savova-Bianchi, D.; Oppliger, A., Assessment of airborne virus contamination in wastewater treatment plants. Environ. Res. 2014, 133, 260-265.

35. Uhrbrand, K.; Schultz, A. C.; Madsen, A. M., Exposure to airborne noroviruses and other bioaerosol components at a wastewater treatment plant in Denmark. Food Environ. Virol. 2011, 3, (3-4), 130-137.

36. Xagoraraki, I.; Yin, Z.; Svambayev, Z., Fate of viruses in water systems. $J$. Enviro. Eng. 2014, 140, (7), 04014020.

37. Quadros, M. E.; Marr, L. C., Silver nanoparticles and total aerosols emitted by nanotechnology-related consumer spray products. Environ. Sci. Technol. 2011, 45, (24), 10713-10719.

38. Daugelavičius, R.; Cvirkaitè, V.; Gaidelytė, A.; Bakienė, E.; GabrènaitėVerkhovskaya, R.; Bamford, D. H., Penetration of enveloped double-stranded RNA bacteriophages $\varphi 13$ and $\varphi 6$ into Pseudomonas syringae cells. J. Virol. 2005, 79, (8), 5017-5026.

39. Nicas, M.; Nazaroff, W. W.; Hubbard, A., Toward understanding the risk of secondary airborne infection: emission of respirable pathogens. J. Occup. Env. Hyg. 2005, 2, (3), 143-154.

40. Carducci, A.; Arrighi, S.; Ruschi, A., Detection of coliphages and enteroviruses in sewage and aerosol from an activated sludge wastewater treatment plant. Lett. Appl. Microbiol. 1995, 21, (3), 207-209.

41. Haas, D.; Reinthaler, F.; Wüst, G.; Posch, J.; Ruckenbauer, G.; Marth, E., Comparative investigation of airborne culturable microorganisms in sewage treatment plants. Cent. Eur. J. Public Health 2002, 10, (1-2), 6-10.

42. Korzeniewska, E.; Filipkowska, Z.; Gotkowska-Płachta, A.; Janczukowicz, W.; Dixon, B.; Czulowska, M., Determination of emitted airborne microorganisms from a BIO-PAK wastewater treatment plant. Water Res. 2009, 43, (11), 2841-2851.

43. Keene, W. C.; Maring, H.; Maben, J. R.; Kieber, D. J.; Pszenny, A. A.; Dahl, E. E.; Izaguirre, M. A.; Davis, A. J.; Long, M. S.; Zhou, X., Chemical and physical characteristics of nascent aerosols produced by bursting bubbles at a model air-sea interface. Journal of Geophysical Research: Atmospheres 2007, 112, (D21). 
44. Slade, J.; VanReken, T.; Mwaniki, G.; Bertman, S.; Stirm, B.; Shepson, P., Aerosol production from the surface of the Great Lakes. Geophysical Research Letters 2010, 37, (18).

45. Clarke, N. A.; Stevenson, R. E.; Chang, S. L.; Kabler, P. W., Removal of enteric viruses from sewage by activated sludge treatment. Am. J. Public Health Nations Health 1961, 51, (8), 1118-1129.

46. Ye, Y.; Ellenberg, R. M.; Graham, K. E.; Wigginton, K. R., Survivability, partitioning, and recovery of enveloped viruses in untreated municipal wastewater. Environ. Sci. Technol. 2016.

47. Towner, J. S.; Rollin, P. E.; Bausch, D. G.; Sanchez, A.; Crary, S. M.; Vincent, M.; Lee, W. F.; Spiropoulou, C. F.; Ksiazek, T. G.; Lukwiya, M., Rapid diagnosis of Ebola hemorrhagic fever by reverse transcription-PCR in an outbreak setting and assessment of patient viral load as a predictor of outcome. J. Virol. 2004, 78, (8), 43304341.

48. Quadros, M. E.; Marr, L. C., Silver nanoparticles and total aerosols emitted by nanotechnology-related consumer spray products. Environ. Sci. Technol. 2011, 45, (24), 10713-10719. 


\section{Chapter 3. Conclusions}

\subsection{Conclusions}

The potential for Ebola virus being aerosolized in wastewater systems is directly related to risk of inhalation exposure for sewer workers. We considered this risk for three wastewater systems: toilets, a lab-scale model of an aeration basin, and a lab-scale model of converging sewer pipes. We measured the aerosol size distribution generated by each system, spiked Ebola virus surrogates into each system, and determined the emission rate of viruses into the air. Our result show the number of aerosols released ranged from $10^{5}$ to $10^{7}$ per flush from the toilets or per minute from the models, and the total volume of aerosols generated by these systems was $\sim 10^{-8}$ to $10^{-7} \mathrm{~mL}$ per flush or per minute in all cases. No viable MS2 and Phi6 were detected in the air samples collected after flushing

toilets. Airborne concentrations of MS2 and Phi6 were $\sim 20 \mathrm{PFU} \mathrm{L}^{-1}$ and $\sim 0.1 \mathrm{PFU} \mathrm{L}^{-1}$, respectively, in the aeration basin and sewer model, making the emission rates varied from 0.3 PFU min ${ }^{-1}$ to $547 \mathrm{PFU} \mathrm{min}^{-1}$ depending on viruses and models. Our results indicated that the risk of exposing to and inhalation Ebola virus after flushing of toilets is low, while the aeration basin and converging sewer pipes models are possible to generate aerosols that contains infectious viruses. Thus, appropriate personal protective equipment is necessary for people who work closely Ebola virus-contaminated wastes. In the meanwhile, the concentration of Ebola virus surrogates in aerosols themselves were higher than their initial concentrations in mixed liquor, which the reason is unknown. The Emission rates from this study can help inform risk assessment of inhalation exposure to Ebola virus. Further investigations are needed to better evaluate the aerosolization of Ebola virus in real wastewater systems scenario. 


\subsection{Recommendations for Future Work}

Future work may include but is not limited to: (1) explore viruses or abiotic alternatives that can better represent Ebola virus and investigate their aerosolization in wastewater systems. Although MS2 and Phi6 are the best biotic surrogates for Ebola virus, they are still different from Ebola virus in the aspects of size, shape and structure or genome types. The effect of these characteristics on the aerosolization of Ebola virus are not clear. (2) investigate the fate and transport of the aerosols contaminated with Ebola virus surrogates in the environment. (3) determine enrichment factors for viruses and other microorganisms that are aerosolized from a liquid. Studies about aerosols migration, persistence of viruses in aerosols, and the interaction between aerosols and other ambient particles will provide valuable information on risk assessment of inhalation exposure to Ebola virus. 